\title{
Gambaran eGFR Menurut CKD-EPI pada Penderita Thalassemia Mayor di Rumah Sakit Dr. Hasan Sadikin Bandung
}

\author{
Rismauli Doloksaribu, ${ }^{1}$ Rizka Husna, ${ }^{2}$ Amaylia Oehadian ${ }^{3}$ \\ ${ }^{1}$ Rumah Sakit Umum Dr. Pirngadi Medan, ${ }^{2}$ Departemen Ilmu Penyakit Dalam Fakultas Kedokteran Universitas \\ Padjadjaran/Rumah Sakit Dr. Hasan Sadikin Bandung, ${ }^{3}$ Divisi Hemato Onkologi Departemen Ilmu Penyakit \\ Dalam Fakultas Kedokteran Universitas Padjadjaran/Rumah Sakit Dr. Hasan Sadikin Bandung
}

\begin{abstract}
Abstrak
Peningkatan harapan hidup penderita thalassemia menyebabkan manifestasi penyakit pada berbagai organ, termasuk ginjal. Estimated glomerular filtration rate (eGFR) adalah penghitungan untuk mendeteksi gangguan dini fungsi ginjal, cara ini lebih dipercaya dibandingkan nilai kreatinin serum. The National Kidney Foundation merekomendasikan Chronic Kidney Disease Epidemiology Collaboration (CKD-EPI) untuk mengestimasi laju filtrasi glomerulus. Penelitian ini bertujuan mengetahui gambaran eGFR menurut CKD-EPI pasien thalassemia. Penelitian menggunakan metode deskriptif. Data diambil dari penderita thalassemia mayor rawat jalan di Klinik Hematologi Onkologi Medik, Rumah Dr. Sakit Hasan Sadikin Bandung, mulai 1 Februari sampai dengan 31 Maret 2016. Diperiksa kadar kreatinin serum dan penghitungan eGFR berdasar atas CKD-EPI. Dari 108 subjek penelitian, didapatkan usia rata-rata 18 tahun dengan jumlah wanita sebanyak 61,1\%. Gambaran eGFR berdasarkan CKDEPI: menunjukkan hiperfiltrasi glomerulus pada mayoritas pasien dengan eGFR $>120 \mathrm{~mL} / \mathrm{menit}$. Pemeriksaan fungsi ginjal pasien thalassemia diperlukan untuk memantau gangguan fungsi ginjal dan untuk pemilihan penggunaan jenis kelasi besi. [MKB. 2016;49(1):22-7]
\end{abstract}

Kata kunci: CKD-EPI, eGFR, thalassemia

\section{eGFR Profile Based on CKD-EPI of Thalassemia Mayor Patients in Dr. Hasan Sadikin General Hospital Bandung}

\begin{abstract}
Increased life expectancy of thalassemia patients has a consequence of various manifestations of the diseases in many organs including kidney. Estimated glomerular filtration rate (eGFR) can be used for detecting early renal dysfunctions due to the fact that this calculation is more accurate compared to creatinine serum measurement. The National Kidney Foundation recommends Chronic Kidney Disease Epidemiology Collaboration (CKD-EPI) for estimating GFR. The aim of this descriptive study was to describe eGFR profile based on CKD-EPI in thalassemia patients. Data were collected from ambulatory patients visiting the Hematology Oncology Medical Clinic of Dr. Hasan Sadikin General Hospital during the period of February 1, 2016 to March 31, 2016. Subjects were patients with thalassemia major. Creatinine serum level and calculated eGFR based on CKD-EPI were evakyated. One hundred and eightsubjects with a median age of 18 years participated in this study with $61.1 \%$ of them were female. According to the Kidney Disease Improving Global Outcomes (KDIGO) 2012, the eGFR calculation based on CKD-EPI showed that the majority of patients experience glomerular hyperfiltration (eGFR $>120 \mathrm{ml} / \mathrm{mnt}$ ). In this study, most Thalassemia major patients showed glomerular hyperfiltration. Renal function test is needed to monitor renal function abnormalities and to choose the type of iron chelation therapy to be implemented. [MKB. 2016;49(1):22-7]
\end{abstract}

Key words: CKD-EPI, eGFR, thalassemia

Korespondensi: Rismauli Doloksaribu, dr., Sp PD, Rumah Sakit Umum Dr. Pirngadi Medan, Jalan Professor H.M. Yamin SH. No.47, Perintis, Medan, Sumatera Utara, mobile: 08126533843, e-mail: rismadoloksaribu@yahoo.com 


\section{Pendahuluan}

Thalassemia merupakan kelainan monogenetik paling umum di seluruh dunia yang menjadi perhatian penting di negara-negara dengan populasi tinggi untuk kelainan ini di antaranya negara-negara daerah Mediterania, Asia Selatan, Asia Tenggara, dan Indonesia salah satunya. ${ }^{1,2}$ Pada thalassemia dijumpai kelainan yang bersifat herediter akibat mutasi gen globin yang menyebabkan berkurangnya atau tidak terdapat sintesis satu atau lebih rantai globin., ${ }^{1,3}$ Dalam praktek klimis dikenal dua tipe thalassemia, yaitu thalassemia $\alpha$ dan thalassemia $\beta$. Thalassemia $\alpha$ diakibatkan oleh berkurang atau tidak terdapat sintesis $\alpha$ - globin, sedangkan thalassemia $\beta$ diakibatkan berkurang atau tidak terdapat sintesis $\beta$ - globin. ${ }^{3}$ Terapi dengan transfusi darah disertai pemakaian kelasi besi baik tunggal maupun kombinasi mengakibatkan peningkatan angka harapan hidup penderita thalassemia. Peningkatan ini menyebabkan manifestasi beberapa morbiditas penyakit thalassemia pada berbagai organ seperti hati, jantung, sistem endokrin termasuk komplikasi pada ginjal. Banyak sekali pemantauan mengenai komplikasi penyakit thalassemia pada berbagai organ, namun sedikit sekali yang melakukan pemantauan terhadap komplikasi ginjal. Penderita thalassemia dapat mengalami gangguan pada ginjal sebagai akibat anemia kronik, kelebihan besi sebagai efek samping transfusi jangka panjang dan sebagai efek samping pemakaian kelasi besi. ${ }^{1,3,4}$

Anemia kronik dapat menyebabkan peningkatan stres oksidatif dan lipid peroksidase yang dapat menyebabkan kerusakan pada sel tubulus ginjal. Anemia kronik juga menyebabkan berkurangnya resistensi vaskular sehingga terjadi peningkatan aliran darah pada ginjal dan meningkatkan laju filtrasi golerulus yang dikenal sebagai hiperfiltrasi. Pada akhirnya keadaan hiperfiltrasi yang berlama lama dapat menyebabkan cedera pada pada sel epitel dan endotel sehingga terjadi gangguan fungsi glomerulus. ${ }^{1,5}$

Akumulasi besi dapat sebagai sumber dari stres oksidatif yang menyebabkan efek toksik pada sel epitel tubulus ginjal dan meningkatkan permeabilitas glomerulus yang pada akhirnya dapat menyebabkan penurunan laju filtrasi glomerulus. ${ }^{1,5}$

Saat ini terdapat tiga jenis kelasi besi (iron chelator), yaitu desferrioxamine, deferiprone dan deferasirox. Ketiga jenis kelasi besi ini dapat menimbulkan perubahan fungsi ginjal mulai dari efek prerenal, yaitu kekurangan cairan yang ditimbulkan oleh diare dan muntah terkait efek samping pemakaian kelasi besi tersebut hingga terjadi nefrotoksik secara spesifik. ${ }^{1,6}$

Baku emas untuk menentukan laju filtrasi glomerulus (glomerular filtration rate/GFR) adalah dengan pemeriksaan klirens inulin. Penelitian yang dilakukan untuk menentukan GFR pada penderita thalassemia $\beta$ mayor dengan menggunakan klirens kreatinin, pemeriksaan cystatin $\mathrm{C}$ serum dan penghitungan nilai estimasi GFR (eGFR). ${ }^{4}$ Nilai kreatinin serum tidak dapat dijadikan penanda gangguan awal fungsi ginjal. The National Kidney Foundation merekomendasikan Chronic Kidney Desease Epidemiology Collaboration (CKD-EPI) untuk penghitungan estimasi laju filtrasi glomerulus (estimated glomerular filtration rate/eGFR) yang dapat dipakai sebagai penilaian dini fungsi ginjal. ${ }^{7,8}$ Wieneke dkk, pada tahun 2010 membandingkan akurasi penghitungan eGFR berdasarkan Cockcroft-Gault, Modification of Diet in Renal Disease (MDRD) dan Chronic Kidney Disease Epidemiology Collaboration (CKD-EPI) dan mendapatkan bahwa CKD-EPI memberikan estimasi yang lebih baik.7

Beberapa penelitian menunjukkan gangguan fungsi ginjal pada populasi thalassemia mayor, seperti pada penelitian yang dilakukan oleh Milo dkk. ${ }^{4}$ yang mendapatkan penurunan nilai GFR pada penderita thalassemia mayor. Penelitian yang dilakukan oleh Mohkam dkk. pada penderita thalassemia mayor mendapatkan kesimpulan gangguan ginjal pada thalassemia mayor akan meningkat sesuai dengan peningkatan usia pasien, peningkatan lama mendapatkan transfusi darah, pemakaian terapi kelasi besi desferrioxamine, dan peningkatan kadar gula darah.

Saat ini belum ada penelitian mengenai gambaran fungsi ginjal pada penderita thalassemia di Rumah Sakit Dr. Hasan Sadikin Bandung. Berdasarkan hal tersebut, peneliti ingin mengetahui bagaimana gambaran eGFR pada penderita thalassemia mayor menurut CKD-EPI di klinik Hematologi Rumah Sakit Umum Pusat Dr. Hasan Sadikin.

\section{Metode}

Penelitian ini menggunakan metode deskriptif. Data yang diambil adalah penderita thalassemia mayor rawat jalan di Klinik Hematologi Onkologi Medik Ilmu Penyakit Dalam Rumah Sakit Dr. Hasan Sadikin Bandung mulai 1 Februari 2016 
sampai dengan 31 Maret 2016. Pemeriksaan kadar kreatinin serum dilakukan pada seluruh subjek sebanyak satu kali pemeriksaan pada saat kunjungan penderita ke poliklinik Hematologi Onkologi Medik untuk mendapatkan tindakan transfusi darah. Pada subjek juga didata mengenai lama menderita thalassemia dan jenis kelasi besi. Kriteria inklusi adalah semua pasien thalassemia mayor yang memiliki data kreatinin serum dan kriteria eksklusi penelitian ini adalah pasien yang tidak ada data kreatininnya dan pasien yang telah diketahui menderita gagal ginjal sebelum penelitian ini dimulai.

Pada pasien dilakukan penghitungan eGFR melalui metode CKD-EPI, yaitu dihitung dengan rumus:

$\mathrm{GFR}=141 \times \min \left(\mathrm{S}_{\mathrm{cr}} / \kappa, 1\right)^{\alpha} \times \max \left(\mathrm{S}_{\mathrm{cr}} / \kappa, 1\right)^{-1.209} \times$ $0.993^{\text {usia }} \times 1.018$ [bila wanita] $\times 1.159$ [kulit hitam]

Keterangan:

$\mathrm{S}_{\mathrm{cr}}$ : kreatinin serum dalam $\mathrm{mg} / \mathrm{dL}$

к: 0.7 untuk wanita dan 0.9 untuk pria

$\alpha$ : -0.329 untuk wanita dan -0.411 untuk pria

min: nilai minimum $\mathrm{S} / \kappa$ atau 1

maks: nilai maksimal $S_{\text {cr }} / \kappa$ atau 1

\section{Hasil}

Dari 135 pasien thalassemia mayor di Klinik Hematologi Onkologi Medik sejak Februari sampai dengan Maret 2016, sebanyak 27 pasien dieksklusi karena 1 pasien telah diketahui menderita gagal ginjal sebelumnya dan 26 pasien tidak memiliki data kreatinin serum. Dari 108 pasien didapatkan karakteristik dasar dari pasien thalassemia yaitu wanita sebanyak $61,1 \%$ (66 pasien), dengan usia rerata pasien 18 tahun. Lama pasien menderita thalassemia terbanyak adalah 16-20 tahun, yaitu sebanyak 48,1 \% (52 pasien), didapatkan 98,1\% pasien memiliki nilai feritin $\geq 1000 \mathrm{ng} / \mathrm{mL}$. Jenis kelasi besi yang digunakan adalah kombinasi dua jenis kelasi besi yaitu 47,2 \% (51 pasien). Karakteristik dasar subjek penelitian dapat dilihat pada tabel 1 .

Gambaran eGFR pada pasien thalassemia berdasarkan CKD-EPI, didapatkan hasil hampir seluruh pasien memiliki eGFR diatas normal yaitu $>120 \mathrm{~mL} /$ menit $/ 1,73 \mathrm{~m}^{2}$ dengan median $154,62 \pm 17,86$, satu pasien dengan nilai eGFR $117,91 \mathrm{~mL} / \mathrm{menit} / 1,73 \mathrm{~m}^{2}$ telah menderita thalassemia mayor selama 9 tahun dengan pada saat penelitian ini tidak mendapat terapi kelasi besi. Distribusi eGFR berdasarkan jenis terapi kelasi besi dapat dilihat pada tabel 2 .

Terdapat 107 pasien yang masuk dalam penelitian menunjukkan nilai eGFR tinggi $>120$ $\mathrm{mL} / \mathrm{menit} / 1,73 \mathrm{~m}^{2}$. Distribusi eGFR berdasar atas kombinasi terapi kelasi besi dapat dilihat pada Tabel 3 dan Gambar 1.

Tabel 1 Karakteristik Dasar Pasien Thalassemia Mayor Klinik Hematologi Onkologi Medik Ilmu Penyakit Dalam RSHS

\begin{tabular}{|c|c|c|}
\hline Karakteristik & $\begin{array}{c}\text { Median (Min-Maks) / Rata-rata } \\
\text { (SD) }\end{array}$ & $\begin{array}{c}\text { Jumlah (\%) } \\
(n=108)\end{array}$ \\
\hline Usia (tahun) & $18(14-52)$ & \\
\hline \multicolumn{3}{|l|}{ Jenis Kelamin } \\
\hline Pria & & $42(39)$ \\
\hline Wanita & & $66(61)$ \\
\hline \multicolumn{3}{|l|}{ Kadar Feritin $(\mathrm{ng} / \mathrm{mL})$} \\
\hline$\geq 1.000$ & & $106(98)$ \\
\hline$<1.000$ & & $2(2)$ \\
\hline \multicolumn{3}{|l|}{$\begin{array}{l}\text { Lama Menderita thalassemia } \\
\text { (tahun) }\end{array}$} \\
\hline $1-5$ & & 0 \\
\hline $6-10$ & & $8(7)$ \\
\hline $11-15$ & & $44(41)$ \\
\hline $16-20$ & & $52(48)$ \\
\hline$>20$ & & $4(4)$ \\
\hline eGFR (mL/menit/1,73 m²) & $154,62 \pm 17,86$ & \\
\hline
\end{tabular}


Rismauli Doloksaribu: Gambaran eGFR Menurut CKD-EPI pada Penderita Thalassemia Mayor di Rumah Sakit Dr. Hasan Sadikin

Tabel 2 Distribusi eGFR berdasar atas Jenis Terapi Kelasi Besi

\begin{tabular}{lccc}
\hline \multirow{2}{*}{ Jenis Kelasi Besi } & Jumlah & Mean \pm SD & Min. - Maks. \\
\cline { 3 - 4 } & 2 & $130,19 \pm 17,36$ & $117,91-142,46$ \\
Tidak ada kelasi besi & 8 & $150,69 \pm 31,20$ & $124,51-222,83$ \\
Desferrioxamine & 14 & $160,95 \pm 17,11$ & $139,40-200,07$ \\
Deferasirox & 26 & $150,06 \pm 17,45$ & $105,97-183,93$ \\
Deferiprone & 12 & $164,21 \pm 18,94$ & $127,94-205,24$ \\
Desferrioxamine dan Deferasirox & 21 & $151,81 \pm 10,34$ & $128,90-166,91$ \\
Desferrioxamine dan Deferiprone & 18 & $155,84 \pm 12,68$ & $132,80-179,60$ \\
Deferiprone dan Deferasirox & 7 & $159,30 \pm 22,00$ & $133,28-202,19$ \\
Desferrioxamine, Deferiprone, dan Deferasirox & & &
\end{tabular}

Kelompok pasien yang memakai kombinasi 2 jenis terapi kelasi besi sebanyak 51 orang. Semua pasien dengan atau tanpa kombinasi terapi kelasi besi menunjukkan nilai eGFR ratarata yang meningkat.

\section{Pembahasan}

Penderita thalassaemia $\beta$ mayor mempunyai risiko gangguan ginjal sebagai akibat dari penyakitnya, kelebihan besi karena transfusi, dan akibat terapi kelasi. ${ }^{9}$ Pada penelitian ini, peningkatan eGFR berdasar atas CKD-EPI didapatkan pada 107 subjek penelitian. Hasil ini berbeda dengan yang dilaporkan oleh Quinn dkk. ${ }^{10}$ yang mendapatkan penurunan gangguan fungsi ginjal pada 7,8\% penderita thalassemia mayor yang mendapat transfusi lebih dari 8 tahun. Penelitian Lai dkk. ${ }^{11}$ mendapatkan hasil eGFR dalam batas normal pada 81,5\% (66/81) subjek thalassemia mayor setelah 10 tahun diagnosis.

Hiperfiltrasi glomerulus pada penderita thalassemia mayor dihubungkan dengan anemia kronik pada pasien. Anemia kronik menyebabkan penurunan resistensi vaskular yang mengakibatkan sirkulasi hiperdimamik, peningkatan aliran plasma pada ginjal, dan peningkatan GFR. Perubahan ini mengakibatkan peregangan dinding kapiler glomerulus, kerusakan endotel dan epitel, yang bersama dengan transudasi makromolekul ke mesangium. Semua ini pada akhirnya menyebabkan gangguan glomerulus, dan pada jangka panjang akhirnya akan menurunkan GFR. Hipoksia kronik pada sel tubulus dapat menyebabkan apoptosis atau transisi sel epitel menjadi sel mesenkimal yang mengakibatkan kerusakan tubulointerstitial, glomerulosklerosis dan fibrosis ginjal. Sebagai tambahan, kerusakan sel tubulus karena kelebihan besi berakibat migrasi sel tubulus ke intersitium, pelepasan sitokin dan faktor pertumbuhan yang menyebabkan jaringan parut tubulointerstitial dan glomerulosklerosis, yang akan menurunkan GFR lebih lanjut. ${ }^{1,12}$

Pada penelitian ini hiperfiltrasi glomerulus dihubungkan dengan keadaan anemia kronik pada pasien, walaupun kami tidak melakukan analisis derajat anemia pada pasien penelitian.

Mayoritas pasien pada penelitian ini memiliki kadar feritin $>1.000 \mathrm{ng} / \mathrm{mL}$. Penelitian Economou dkk. ${ }^{13}$ pada penderita thalassemia $\beta$ mayor, mendapatkan hasil $54,5 \%$ subjek

Tabel 3 Distribusi eGFR berdasar atas Kombinasi Terapi Kelasi Besi

\begin{tabular}{lccc}
\hline \multirow{2}{*}{ Jenis Kelasi Besi } & \multirow{2}{*}{ Jumlah } & \multicolumn{2}{c}{ eGFR } \\
\cline { 3 - 4 } & & Mean \pm SD & Min. - Maks. \\
\hline Tidak ada kelasi besi & 2 & $130,19 \pm 17,36$ & $117,91-142,46$ \\
1 jenis kelasi besi & 48 & $153,34 \pm 20,31$ & $105,97-222,83$ \\
2 jenis kelasi besi & 51 & $156,15 \pm 14,14$ & $127,94-205,24$ \\
3 jenis kelasi besi & 7 & $159,30 \pm 22,00$ & $133,28-202,19$ \\
\hline
\end{tabular}




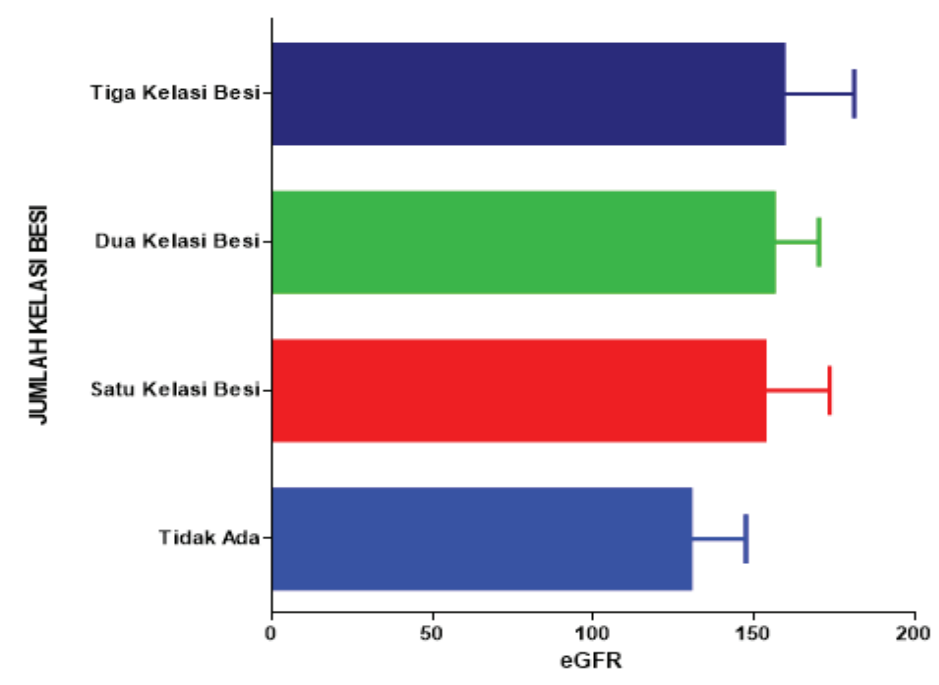

Gambar 1 Distribusi eGFR berdasar atas Kombinasi Terapi Kelasi Besi

mempunyai kadar feritin $>1.000 \mathrm{ng} / \mathrm{mL}$ dan menyatakan kadar feritin tinggi tidak dapat digunakan sebagai prediktor bebas terjadinya gangguan fungsi ginjal baik gangguan fungsi glomerulus ataupun tubulus karena kadar feritin tidak dapat menggambarkan ringan atau beratnya hemosiderosis yang terjadi pada ginjal dan terapi kelasi besi saja tidak cukup untuk mengurangi akumulasi besi pada ginjal.

Nilai eGFR pada penelitian ini tetap tinggi walaupun pasien mendapatkan jenis dan kombinasi terapi kelasi besi yang berbeda. Gangguan fungsi ginjal yang dilaporkan akibat pemakaian terapi kelasi besi bervariasi dari ringan berupa peningkatan kreatinin serum yang reversibel sampai dengan terjadi acute kidney injury (AKI). ${ }^{1}$ Penelitian Koren dkk. ${ }^{13}$ melaporkan pemberian desferrioxamine subkutan berhubungan dengan penurunan GFR secara bermakna pada $40 \%$ penderita thalassemia mayor dan penurunan ringan GFR pada $40 \%$ subjek yang diteliti. Toksisitas ini bergantung pada dosis yang digunakan.Pemakaian kelasi besi desferrioxamine dilaporkan dapat menyebabkan gagal ginjal akut pada pasien yang mengalami overdosis 4,8

Terdapat beberapa laporan mengenai kemungkinan nefrotoksik akibat deferasirox. Disfungsi tubulus dilaporkan pada pasien yang menggunakan deferasirox. Sebuah penelitian fase 3 yang membandingkan deferasirox versus desferrioxamine pada pasien thalassemia $\beta$ mayor, didapatkan hasil peningkatan kreatinin serum pada $38 \%$ pasien yang mendapatkan terapi deferasirox dengan dosis 20-30 mg/ $\mathrm{kg}$ dibandingkan $14 \%$ pasien yang mendapat desferrioxamine. ${ }^{8}$ Penelitian yang dilakukan oleh Piga dkk. ${ }^{9}$ mendapatkan hasil penurunan GFR pada pemakaian deferasirox dan nilai GFR akan mengalami perbaikan setelah penghentian obat ini. Deferipone oral dikatakan cukup aman untuk ginjal. ${ }^{1,14}$

Penyebab pasti mekanisme kerusakan ginjal akibat pemakaian kelasi besi masih belum diketahui dan membutuhkan penelitian lebih lanjut. ${ }^{1}$ Pada pemakaian deferasirox, diduga penyebab peningkatan kreatinin secara reversibel akibat efek farmakologik deferasirox terhadap intraglomerular hemodinamik ginjal. Hal lain yang dapat menyebabkan peningkatan kreatinin adalah karena kelebihan obat relatif dibanding dengan jumLah besi yang dikelasi. Tanpa cukup besi yang dikelasi, deferasirox akan memindahkan besi dari enzim-enzim yang mengatur filtrasi glomerulus. Pengeluaran besi yang cepat dapat menimbulkan kekurangan besi relatif sehingga merusak mitokondria sel tubulus, aktivasi tubuloglomerular feedback, dan vasokonstriksi yang berakhir pada penurunan GFR. ${ }^{9}$ Pemakaian desferrioxamine dosis tinggi dapat menyebabkan perubahan fungsi ginjal dan pemakaian deferiprone dilaporkan relatif aman untuk ginjal.1,14 Terjadinya gangguan ginjal pada penderita thalassemia memerlukan pengawasan fungsi ginjal yang rutin. Walaupun tidak ada bukti kuat untuk menentukan kapan sebaiknya dilakukan pemeriksaan fungsi ginjal, tetapi pengukuran fungsi ginjal dianjurkan 
paling tidak setiap 3 bulan sekali atau lebih sering pada penderita thalassemia dengan terapi kelasi besi. ${ }^{15}$

Penelitian ini mempunyai kelemahan, yaitu tidak dilakukan evaluasi terhadap derajat anemia pasien. Simpulan, sebagian besar penderita thalassemia mayor menunjukkan hiperfiltrasi glomerulus. Hiperfiltrasi glomerulus yang berlangsung lama dapat mengakibatkan penurunan fungsi ginjal dan gagal ginjal. Pemeriksaan fungsi ginjal rutin pada penderita thalassemia diperlukan untuk memantau gangguan fungsi ginjal dan untuk pemilihan jenis terapi kelasi besi.

\section{Daftar Pustaka}

1. Bhandari S, Galanello R. Renal aspects of thalassaemia a changing paradigm. Eur J Haematol. 2012;89(3):187-97.

2. Mansi K, Aburjai T, AlBashtawy M, AbdelDayem M. Biochemical factors relevant to kidney functions among Jordanian children with beta-thalassemia major treated with deferoxamine. Int J Med Med Sci. 2013;5(8): 374-9.

3. Sumantri R, Supandiman I, Fadjari TH, Fianza PI, Oehadian A, Wijaya I, penyunting. Pedoman diagnosis dan terapi hematologi onkologi medik. Pusat Informasi Ilmiah (PII). Jakarta: Departemen Ilmu Penyakit Dalam; 2011.

4. Milo G, Nevo RFG, Pazgal I, Gafter-Gvili A, Shpilberg O, Gafter U, dkk. GFR in patients with $\beta$-thalassemia major. Clin J Am Soc Nephrol. 2015;10(8):1350-6.

5. Sadeghi-Bojd S, Hashemi M, Karimi M. Renal tubular function in patients with betathalassaemia major in Zahedan, Southeast Iran. Singapore Med J. 2008;49(5):410-2.

6. Mallat NS, Mallat SG, Musallam KM, Taher AT. Potential mechanisms for renal damage in beta-thalassemia. Societa Italiana di Nefrologia. 2013;26(5):821-8.
7. Michels WM, Grootendorst DC, Verduijn M, Elliott EG, Dekker FW, Krediet RT. Performance of the cockcroft-gault, MDRD, and New CKD-EPI formulas in relation to GFR, age, and body size. Clin J Am Soc Nephrol. 2010;5(6):1003-9.

8. Eknoyan G, Lameire N. KDIGO 2012 Clinical practice guideline fo the evalution and management of chronic kidney disease. The International Society of Nephrology. 2012;3(1):1-163.

9. Piga A, Fracchia S, Lai ME, Cappellini MD, Hirschberg R, Habr D, dkk. Deferasirox effect on renal haemodynamic parameters in patients with transfusiondependent $\beta$ thalassaemia. Br J Haematol. 2015;168(6):882-90.

10. Quinn C, Johnson V, Kim H, Trachtenberg F, Vogiatzi M, Kwiatkowski J, dkk. Renal dysfunction in patients with thalassaemia. Br J Haematol. 2011;153(1):111-7.

11. Lai ME, Spiga A, Vacquer S, Carta MP, Corrias C, Ponticelli C. Renal function in patients with $\beta$-thalassaemia major: a long-term follow-up study. NDT. 2012;27(9):3547-51.

12. Khaled M. Musallam ATT. Mechanisms of renal disease in $\beta$-thalassemia. J Am Soc Nephrol. 2012;23(8):1299-302.

13. Economou M, Printza N, Teli A, Tzimouli V, Tsatra I, Papachristou F, dkk. Renal dysfunction in patients with betathalassemia major receiving iron chelation therapy either with deferoxamine and deferiprone or with deferasirox. Acta Haematologica. 2010;123(3):148-52

14. Verissimo MP, Loggetto SR, Baldanzi GR, Hamerschlak N, Fernandes JL, Fertrin KY, dkk. Brazilian thalassemia association protocol for iron chelation therapy in patients under regular transfusion. Rev Bras Hematol Hemoter. 2013;35(6):428-34

15. Ponticelli C, Musallam KM, Cianciulli $P$, Cappellini MD. Renal complications in transfusion-dependent beta thalassemia. Blood Rev. 2010;24(6):239-44. 